\title{
CONSIDERATIONS ON FISCAL HARMONIZATION IN THE EU IN THE FIELD OF VALUE ADDED TAX
}

\author{
Ioan Lazăr ${ }^{1}$ \\ Laura Lazăr ${ }^{2}$
}

\begin{abstract}
The proper functioning of the European internal market would be impossible without fiscal harmonization. The main objective of fiscal harmonization process is the prevention of distortions of the competitive process and the attainment of an equitable allocation of financial resources between Member States. The aim is not to realize a uniform tax system for the Member States of the Union, but achieving a minimum level of harmonization of the national tax systems, in order to prevent harmful fiscal competition between member States. The paper at hand presents the major aspects of fiscal harmonization in general and some aspects of fiscal harmonization in the field of value added tax (VAT) from an interdisciplinary perspective. The paper analyzes the major legal instruments used in the context of the harmonization process. It also refers to the main obstacles in achieving the objective of harmonization, such as the rule of unanimity at the adoption of measures at the Union level and proposes some solutions. The authors also try to explain why the directives are the mainly used legislative instruments in the context of harmonization process. The ultimate objective of the recent adopted EU tax rules in the field is the creation of a tax system based on the principle of taxation at the origin, in order to reduce the administrative burden on taxpayer and to prevent illegal capital movement between Member States. The final part of the paper presents the major characteristics of the actual common system of VAT applicable in the European Union and mentions some of the major obstacles in attaining the above mentioned objective regarding the establishment of a more efficient tax system in the field of VAT.
\end{abstract}

Keywords: fiscal harmonization, EU tax policy, national tax systems, Value Added Tax (VAT), common VAT system;

JEL Codes: K34, H21, H25, H32

Introduction

Transition from a simple custom union to a monetary and economic union of the $27 \mathrm{Member}$ States implies, besides the four basic freedoms (the free movement of goods, services, people and capital) also the integration and harmonization of national economic policies and also the introduction of a single currency (Minea, Costaş, 2006:315; Fábián, 2008: 103). Thus, national tax policies have undergone a process of harmonization. Deepening economic integration led to greater interaction between the tax systems of Member States, as effect of the amplification of the cross border movement of goods and inputs.

In this context, major differences between the national tax systems of Member States (especially as regards indirect taxes) could generate distortions in the competitive process (Drăgoi, Lazăr, 2009: 163) and can lead to an inequitable allocation of financial resources among Member States, giving rise to a harmful fiscal competition. That's why the simple spontaneous coordination between Member States was not sufficient to ensure the proper functioning of the internal market of

\footnotetext{
${ }^{1}$ Junior Teaching Assistant, PhD. Student, Faculty of Law and Social Sciences „1Decembrie 1918” University of Alba Iulia, Lawyer, Alba Bar

${ }^{2} \mathrm{PhD}$. Student Faculty of Economics and Business Administration „Babeş-Bolyai” University of Cluj-Napoca
} 
the Union. So the harmonization of the national tax laws and the insurance of a proper framework for cooperation between national tax authorities was a necessity.

The paper at hand aims to provide for the reader a general insight on the tax harmonization process in general and especially on the harmonization process in the field of the most important indirect tax, the value added tax. The paper will not insist on highly technical aspects of the harmonization process, this being the job of specialists, but it will present the actual degree of harmonization achieved between national tax rules. Being an interdisciplinary paper, it will also insist on legal aspects, such as the norms of the Union which are applicable in the mentioned context.

\section{General aspects of fiscal harmonization between member states}

Fiscal harmonization does not imply a perfect overlap of the national tax systems, but achieving convergence between national systems, by attainment of an ordered and coherent whole. The major objective is ensuring the proper functioning of the single market (Donath, Şeulean, 2006: 13-16). So, the appropriate measure of harmonization is one that eliminates those disparities between national tax systems who distort the allocation of resources between Member States. Moreover, we must mention that the attainment of a uniform tax system has no legal foundation and is contrary to the subsidiarity principle (Fábián, 2008: 70-74). Considering that Member States has particular economic and demographic characteristics, the attainment of a uniform tax system has not even an economic rationality. Thus, Member States has to use fiscal levers in different ways, in order to achieve different economic and social objectives. The mentioned viewpoint was shared also by the authors of the Neumark Report (1963), realized by the Tax and Financial Committee set up by the Council of the European Union. The authors of the report were in favor of maintaining particular national rules which not endanger the Community objectives (Minea, Costaş, 2006: 320).

The highest level of harmonization must be attained in the field of indirect taxes, because the differences in terms of indirect taxes determine different prices for the consumers and so contribute to the delimitation of national markets, this being incompatible with the objectives of internal market (Minea, 2003: 38-43; Bufan et al., 2008: 69; Negrescu et al., 2007). Regarding the process of harmonization of national tax laws, we should see what are those policy measures and instruments which support the mentioned process.

According to Article 288 of the Treaty on the Functioning of the European Union, the institutions of the Unoin have the possibility to adopt regulations, directives, decisions, recommendations and opinions. So, the article 288 of the mentioned Treaty says: "to exercise the Union's competences, the institutions shall adopt regulations, directives, decisions, recommendations and opinions".

In the following we will analyze the characteristics of the legislative measures mentioned and see which of them is suitable to achieve the objective of the harmonization of the national tax systems.

The regulations are the Union's legislative acts with the biggest coercitive force, binding in its entirety and directly applicable in all Member States (Cairns, 1997: 87-95; Deleanu, 2007: 114). Unlike regulations, directives are legislative acts which prescribes both results to be achieved and means to achieve them. It let Member States a greater freedom of action, prescribing only results to be achieved, without setting the concrete ways in which those results have to be achieved by the Member States.

In these circumstances it is no wonder that the majority of rules on indirect taxes are included in directives and not regulations. This reality confirms the fact that Member States are reluctant to accept supranational regulation in the filed of fiscality. We also mention the fact that regulations in the field of fiscality are adopted by unanimity, and not by qualified majority (Article 114 of the Treaty on the Fuctioning of the European Union ). Thus, as it was found in the doctrine, fiscal harmonization is hampered in general by two obstacles: the rule of unanimity within the rule 
making process and the lack of consensus regarding the necessity of such a step (Negrescu et al., 2007: 11-14).

In the doctrine (Negrescu et al., 2007: 12) several solutions were proposed to exit deadlock, such as: i) voting with qualified majority as regards combating fiscal fraud, prevention of double taxation, fiscal measures in the field of environment protection. In our opinion such a solution does not seams a realistic one taking into account the norms of the Union's treaties; ii) the adoption of legislative measures called „soft-laws”, i.e. legislative instruments without a binding character (e.g. codes of conduct, best practices, recommendations, guidelines of the European Commission); iii) adoption of legislation as legislative packages, by grouping the legislative proposals coming from the Commission. In such a context, even if some of the legislative proposals included in the package are unfavorable for some of the Member States there are greater chances of approval, if the rest of the legal proposals that are in the package are favorable for the Member States.

\section{Fiscal harmonization versus tax competition}

The concept of tax competition was defined in the literature as the activity of independent governments which engage in wasteful competition for scarce capital through reductions in tax rates and public expenditure levels (Wilson, 1999: 269). Some authors also highlighted the negative effects of this phenomenon and mentioned the fact that tax competition will reduce public spending and contribute to the creation of inefficiencies. So, it was noted that none of the governments which engage themselves in tax competition will gain a competitive advantage from such an activity and national communities will be worse off (Wilson, 1999: 269). There were also other opinions, according to which fiscal harmonization based on the idea of centralization creates also negative effects, just because it reduces competition between national governments, impeding the creation of low taxation systems, which are beneficial for consumers (Eusepi, Schneider, 2004: 49). According to the opinion of the above mentioned authors, the two approaches - respectively tax competition and tax harmonization - are based on different ideological orientations. Thus, fiscal harmonization is based on the ideology of the welfare economy, while tax competition is based on the constitutional political economy. They considered that fiscal harmonization has as effect a fiscal centralization, while tax competition creates efficiency in production.

It was also mentioned the fact that different tax levels are justified because of the differences which exists between the Member States in terms of economic growth (Eusepi, Schneider, 2004: 51). The positive and negative effects of fiscal harmonization and tax competition are best reflected if we analyze the hypothetic example of fiscal harmonization, respective tax competition in the case of two neighboring countries, named A and B (Eusepi, Schneider, 2004: 60-63).

The first example illustrates the effects of fiscal harmonization between two countries $A$ and $\mathrm{B}$, where the level of taxes required are at a superior level in country $\mathrm{B}$ and the fiscal harmonization process implies an increase of the tax level of country A: i) in the context of tax harmonization the consumers of country B, which were used to purchase products from the state A, will support an increase in price level; ii) the demand for the goods produced in country B will increase, which will lead to an increase of the production and implicitly will cause a price reduction; iii) the surplus of producers from country B will increase, because of the reduction of competition which comes from the goods produced in state A; iv) the government of state B benefits from increased tax revenues due to increased production; v) the consumers from country A pay higher prices due to increased taxes; vi) the government of country A earns higher incomes due to increased taxes.

The second example, illustrates the effects of tax competition between two countries A and B, where country A reduces the taxes applicable for goods and services which forms object of export obligations, thus competing the producers from country B. Taking into consideration the fact that the action of country A, implies a reaction from the government of country B in the form of tax reductions, the major implications are as follows: i) beneficial effects for the consumers from country B due to the reduction of prices; ii) consumers from country A are also paying reduced 
prices; iii) the governments from the two countries are facing the problem of the reduction of public revenues; iv) the producers from country $\mathrm{B}$ benefits from an increase of production due to an increase of demand; v) the exports of producers from country A will decrease.

As a prime conclusion we can say that the effects of fiscal harmonization and tax competition are both positive and negative, depending on the perspective from which we look at things. Fiscal harmonization is efficient from the point of view of the governments, because it prevents harmful competition between them. On the other hand, consumers benefits from reduced prices in the presence of tax competition.

\section{Fiscal harmonization in the field of valuea added tax}

At the beginning we have to clarify the concept of Value Added Tax (Ebrill et. al., 2001: 813; Bird, Gendron, 2007: 10-28). VAT in the European Union represents a general tax levied on consumption, with a broad tax base, being applicable for almost all goods and services which are purchased and resold in the European Union. Therefore, the exported goods or services supplied to consumers established outside the Union are exempted from VAT obligations. Instead, imports from third countries are taxed in order to maintain an equitable tax system for European producers, so they can compete on equal terms with foreign suppliers coming outside from the EU.

We also have to mention that VAT represents a tax charged in every stage on the added value resulted after each stage of the production and distribution, it being proportionate with the price of goods and services. At the same time, VAT is the only tax on turnover applied in the European Union. Thus at the time of establishment of the European Communities the six Member States were using various forms of indirect taxation. These were taxes applied at every stage of the production process and were included in the sale price of the product, determining the exact value of tax included in the price of a particular product being impossible. Consequently, the dangers of financing exports by Member States, deliberately or accidentally, by overestimating the amount of tax deductible had to be considered. Thus, the establishment of a transparent and neutral indirect tax system within the Union was a necessity, in order to ensure the proper functioning of the single market. The actual system ensures the deduction of the exact amount of tax paid in the previous stage of the production and distribution chain and ensures the tax free character of exports.

The ultimate goal of the harmonization process is the attainment of a genuine common market, by removing fiscal barriers, by eliminating the import taxes for products which comes from the Member States and by refunding export tax. In order to reduce administrative burden and to accomplish with the objective mentioned above, the Commission proposed on several occasion the transition to a system of taxation which complies with the principle of taxation at the origin, which prevents the unjustified movements of capital from one Member State to another. Yet, until the attainment of the mentioned objective, from the $1^{\text {st }}$ of January 1993 was set a taxation system which combines the principle of taxation at the origin with the principle of taxation at the destination (i.e. in the Member State were produces are consumed).

\section{Some considerations on council directive no. 2006/112/EC on the common system of value added tax}

The directive mentioned above represents a codification of provisions that aim to implement the common VAT system applicable to production and distribution of goods and services purchased and/or sold for consumption in the European Union. In the following we will refer to the main elements of the common VAT system, such as: taxable transaction, the place where these transactions are considered to take place, VAT rates applicable for different categories of goods and services (Annex no.1) etc.

According to the provisions of the directive, are taxable transactions if they take place within the EU: i) deliveries of goods made by a taxpayer; ii) acquisitions of goods made within the 
EU, consisting in the purchase of goods from another Member State; iii) provision of services by a taxpayer; iv) import of goods from third countries.

As regards the territorial scope of the provisions of the VAT Directive, we have to mention that the following territories are excluded from the scope of the common VAT system: the island of Heligoland and the territory of Buesingen (Germany); the Spanish possessions in Africa, Ceuta and Mellila; the Italian territories Livigno, Campione d'Italia and the Italian waters of the Lake Lugano; the Mount of Athos (Greece); the Canary Islands (Spain); the French overseas territories, Martinique, Guadelpa, and the French Guyana; the Åland Islands (Finland); the Channel Islands (Guernsey, Jersey, Alderney, etc.). We also mention, that according to the Treaty, VAT does not applies in Gibraltar or the part of Cyprus which is located under the effective control of the Government of Cyprus, these being areas considered third territories.

According to the VAT Directive is considered taxable person, any person, who by an independent manner and regardless of location performs an economic activity, whatever the purpose or outcome of this activity is. Such economic activities include the ones of the producers, traders and service providers, including mining, agricultural activities, independent professional activities and those assimilated. Employees or persons who act on the basis of a labor contract or those who are in an employer/employee relationship are not regarded as acting in an independent manner. We also mention that the State, the public institutions, the governmental bodies, local and regional authorities and other public bodies are not considered taxable persons for the activities which they carry out in their capacity as public authorities, except some special situations. However, in cases where the mentioned entities carry out certain operations of a commercial nature, they are treated as taxable persons.

Regarding the place where the transactions take place, we have to mention that it is different depending on the nature of a certain transaction: supplies of goods, acquisitions, provision of services taking place within the European Union.

The tax base varies depending on the nature of the transaction. VAT becomes chargeable when the goods and services are provided, except some explicitly mentioned situations.

As regards VAT rates, we mention that taxable transactions are taxed according to tax rates and conditions set by the Member State in which such transactions are considered to take place. The basic tax rate is determined as a percentage calculated on the tax base and since the $1^{\text {st }}$ of January 2006, until the $31^{\text {st }}$ of December 2010, it could not be less than 15\% (Article 97, par. 1 of the VAT Directive ).

According to Article 98 of the VAT Directive, Member States have the possibility to apply one or two reduced tax rate, at least 5\%. Reduced rates may apply only to supply of goods and services included in Annex no. 3 of the VAT Directive.

However, under certain circumstances, Member States can apply a super-reduced rate of VAT for deliveries of natural gas, electricity and heat supply. Furthermore, the Council authorized the Member States which applied before $31^{\text {st }}$ of March 2006 reduced rates for certain services provided to end consumers who require intensive use of labor, to continue to apply reduced or super-reduced rates for these services, until the $31^{\text {st }}$ of December 2010. Here, we mention in this category activities such as reparing shoes, renovation and repair of private homes, hairdressing etc.

According to a directive proposal of the European Commission on VAT rates, Member States should be granted a greater flexibility in applying VAT rates in areas where EU tax and trade revenues would not be affected. The proposal envisages products and services for which the application of reduced rates would not generate a massive increase of volume of purchases from abroad, which would cause great losses in terms of tax revenue for governments to continue to apply higher rates of VAT. When the proposed directive will be adopted by Member States, its provisions will take effect from the $1^{\text {st }}$ of January 2011, and the list of products / services for which Member States may apply reduced VAT rates will also include activities such as: I) housing (construction, repair, alteration, maintenance and cleaning), ii) restaurant and catering services; iii) 
locally provided services, such as minor repairs of shoes, clothes, computers, etc., cleaning and maintenance services (ironing, washing etc.) iv) personal care (hairdressing, cosmetics); v) gardening and landscaping services.

Also, according to the proposal, Member States may apply reduced VAT rates for products such as nappies, equipment for disabled persons and audio books. The aim of the new provisions would be to diversify the range of products / services for which Member States can apply a reduced VAT rate. Possible advantages of the new provisions will be: the decrease of the products/services prices, fostering the economic growth by encouraging consumers to spend more and creating permanent jobs in sectors that use unskilled labor force.

\section{Conclusions}

Fiscal harmonization of national tax systems of Member States, especially in what regards indirect taxes is necessary in order to prevent distortions of the competitive process and an inequitable location of financial resources among Member States. Tax competition will reduce public spending and will contribute to the creation of economic inefficiencies; due to the fact the no one of the governments engaged in tax competition will gain a competitive advantage. However, both fiscal harmonization and tax competition has also positive and negative effects, as we have seen above.

Tax harmonization is a complex and lasting process, requiring concrete measures to achieve the approximation of national tax laws. As we have seen, the measures adopted by legislature of the European Union must necessarily be supplemented by principles arising from the case law of the Court of Justice. The mentioned institution plays an essential role in the interpretation of EU tax legislation and is showing the situations in which the actions of national authorities are not in accordance with the provisions of the EU.

EU tax legislation is composed mainly of EU directives, such legislative acts being preferred, because let Member States greater freedom of action, so they can choose the means by which to achieve the objectives stipulated therein.

The level of harmonization in the filed of indirect taxes in general and in the field of value added tax, in particular, is very high, the same principles being applicable in all Member States. However, Member States are free to determine the effective tax rates within the limits set by the EU legislation.

Currently, the rules are complicated because some countries benefits from exemption clauses that allow them to apply reduced rates for certain products / services (due to practice on the application of VAT rates in these countries, applicable before the country joined the EU).

The long term objective remains to ensure the transition from a taxation system based on the principle of taxation at the origin to a system of taxation based on the principle of taxation at the destination (i.e. in the country where products are consumed). Another objective remains to simplify the application of VAT in the context of elimination of border controls, the internationalization of production, increased mobility of tax bases and technological development.

However, prior to the transition there are problems that need to be addressed, or this thing requires time and above all, it needs measures to be taken by the Member States. The reality is that Member States seem willing to give up their fiscal sovereignty only in some areas and only to the extent that is necessary. 


\section{References}

1. Bird, R., M., Gendron, P., 2007. The VAT in Developing and Transitional Countries, Cambridge University Press, Cambridge

2. Bufan, R., et al., 2008. Codul fiscal comentat, Wolters Kluwer, București

3. Cairns, W., 1997. Introduction in European Union Law, Cavendish Publishing Limited, Londra

4. Deleanu, I., 2007. Tratat de procedură civilă, vol I., Second Edition, C.H. Beck Publishing House, Bucureşti

5. Donath, L., Şeulean, V., 2006. Competiție fiscală şi armonizare fiscală. Curierul fiscal 2

6. Drăgoi, A., Lazăr, I., 2009. Drept financiar, Risoprint, Cluj-Napoca

7. Ebrill, L., et al., 2001. The Modern VAT, International Monetary Fund, Washington

8. Eusepi, G., Schneider, F., 2004. Changing institutions in the European Union a public choice perspective, Edward Elgar Publishing Limited, Cheltenham

9. Fábián, G., 2008. Drept instituțional comunitar, Sfera Juridică, Cluj-Napoca

10. Minea, M., Şt., Costaş, C., F., 2006. Fiscalitatea în Europa la începutul mileniului III, Rosetti, Bucureşti

11. Minea, M., Şt., 2003. Dreptul fisscal comunitar şi construcția europeană. Studia Universitatis UBB seria Iurisprudentia 1

12. Negrescu, D., et al., 2007. Tendințe de armonizare fiscală la nivelul Uniunii Europene. Provocări pentru România - Study POS 2007, Institutul European din România, Bucharest, available online at http://www.ier.ro/;

13. Wilson, J., D., 1999. Theories of Tax Competition. National Tax Journal 6; 
THE EVOLUTION OF VAT RATES APPLICABLE IN THE MEMBER STATES

\begin{tabular}{|c|c|c|c|c|}
\hline $\begin{array}{c}\text { MEMBER } \\
\text { STATES AND } \\
\text { DATES }\end{array}$ & REDUCED RATE & $\begin{array}{l}\text { STANDARD } \\
\text { RATE }\end{array}$ & $\begin{array}{c}\text { INCREASED } \\
\text { RATE }\end{array}$ & $\begin{array}{l}\text { PARKING } \\
\text { RATE }\end{array}$ \\
\hline \multicolumn{5}{|c|}{ BELGIUM } \\
\hline $1 / 01 / 1971$ & 6 & 18 & 25 & 14 \\
\hline $1 / 01 / 1978$ & 6 & 16 & 25 & - \\
\hline $1 / 12 / 1980$ & 6 & 16 & $25 / 25+5$ & - \\
\hline $1 / 07 / 1981$ & 6 & 17 & $25 / 25+5$ & - \\
\hline $1 / 09 / 1981$ & 6 & 17 & $25 / 25+8$ & - \\
\hline $1 / 03 / 1982$ & $1 / 6$ & 17 & $25 / 25+8$ & - \\
\hline $1 / 01 / 1983$ & $1 / 6$ & 19 & $25 / 25+8$ & 17 \\
\hline $1 / 04 / 1992$ & $1 / 6 / 12$ & 19,5 & - & - \\
\hline $1 / 01 / 1994$ & $1 / 6 / 12$ & 20,5 & - & 12 \\
\hline $1 / 01 / 1996$ & $1 / 6 / 12$ & 21 & - & 12 \\
\hline $1 / 01 / 2000$ & $6 / 12$ & 21 & - & 12 \\
\hline \multicolumn{5}{|c|}{ BULGARIA } \\
\hline $1 / 04 / 1994$ & - & 18 & - & - \\
\hline $1 / 07 / 1996$ & - & 22 & - & - \\
\hline $1 / 01 / 1999$ & - & 20 & - & - \\
\hline $1 / 01 / 2007$ & 7 & 20 & - & - \\
\hline \multicolumn{5}{|c|}{ CZECH REPUBLIC } \\
\hline $1 / 01 / 1993$ & 5 & 23 & - & - \\
\hline $1 / 01 / 1995$ & 5 & 22 & - & - \\
\hline $1 / 05 / 2004$ & 5 & 19 & - & - \\
\hline $1 / 01 / 2008$ & 9 & 19 & - & - \\
\hline $1 / 01 / 2010$ & 10 & 20 & - & - \\
\hline \multicolumn{5}{|c|}{ DENMARK } \\
\hline $3 / 07 / 1967$ & - & 10 & - & - \\
\hline $1 / 04 / 1968$ & - & 12,5 & - & - \\
\hline $29 / 06 / 1970$ & - & 15 & - & - \\
\hline 29/09/1975 & 9,25 & 15 & - & - \\
\hline $1 / 03 / 1976$ & - & 15 & - & - \\
\hline $3 / 10 / 1977$ & - & 18 & - & - \\
\hline $1 / 10 / 1978$ & - & 20,25 & - & - \\
\hline $30 / 06 / 1980$ & - & 22 & - & - \\
\hline $1 / 01 / 1992$ & - & 25 & - & - \\
\hline \multicolumn{5}{|c|}{ GERMANY } \\
\hline $1 / 01 / 1968$ & 5 & 10 & - & - \\
\hline $1 / 07 / 1968$ & 5,5 & 11 & - & - \\
\hline $1 / 01 / 1978$ & 6 & 12 & - & - \\
\hline $1 / 07 / 1979$ & 6,5 & 13 & - & - \\
\hline $1 / 07 / 1983$ & 7 & 14 & - & - \\
\hline $1 / 01 / 1993$ & 7 & 15 & - & - \\
\hline $1 / 04 / 1998$ & 7 & 16 & - & - \\
\hline $1 / 01 / 2007$ & 7 & 19 & - & - \\
\hline \multicolumn{5}{|c|}{ ESTONIA } \\
\hline 1991 & - & 10 & - & - \\
\hline $1993-\ldots$ & - & 18 & - & - \\
\hline $2000-2008$ & 5 & 18 & - & - \\
\hline $01 / 01 / 2009$ & 9 & 18 & - & - \\
\hline
\end{tabular}




\begin{tabular}{|c|c|c|c|c|}
\hline $01 / 07 / 2009$ & 9 & 20 & - & - \\
\hline \multicolumn{5}{|c|}{ GREECE } \\
\hline $1 / 01 / 1987$ & $3 / 6$ & 18 & 36 & - \\
\hline $1 / 01 / 1988$ & $3 / 6$ & 16 & 36 & - \\
\hline 28/04/1990 4 & $4 / 8$ & 18 & 36 & - \\
\hline 8/08/1992 & $4 / 8$ & 18 & - & - \\
\hline $1 / 04 / 2005$ & $4,5 / 9$ & 19 & - & - \\
\hline $15 / 03 / 2010$ & $5 / 10$ & 21 & - & - \\
\hline $1 / 07 / 2010$ & $5,5 / 11$ & 23 & - & - \\
\hline \multicolumn{5}{|c|}{ SPAIN } \\
\hline $1 / 01 / 1986$ & 6 & 12 & 33 & - \\
\hline $1 / 01 / 1992$ & 6 & 13 & 28 & - \\
\hline $1 / 08 / 1992$ & 6 & 15 & 28 & - \\
\hline $1 / 01 / 1993$ & $3 / 6$ & 15 & - & - \\
\hline $1 / 01 / 1995$ & $4 / 7$ & 16 & - & - \\
\hline $1 / 07 / 2010$ & $4 / 8$ & 18 & - & - \\
\hline \multicolumn{5}{|c|}{ FRANCE } \\
\hline $1 / 01 / 1968$ & 6 & 16,6 & 20 & 13 \\
\hline $1 / 12 / 1968$ & 7 & 19 & 25 & 15 \\
\hline $1 / 01 / 1970$ & 7,5 & 23 & 33,3 & 17,6 \\
\hline $1 / 01 / 1973$ & 7 & 20 & 33,3 & 17,6 \\
\hline $1 / 01 / 1977$ & 7 & 17,6 & 33,3 & - \\
\hline $1 / 07 / 1982$ & $4 / 5,5 / 7$ & 18,6 & 33,3 & - \\
\hline $1 / 01 / 1986$ & $4 / 5,5 / 7$ & 18,6 & 33,3 & - \\
\hline $1 / 07 / 1986$ & $2,1 / 4 / 5,5 / 7 / 13$ & 18,6 & 33,3 & - \\
\hline 17/09/1987 & $2,1 / 4 / 5,5 / 7 / 13$ & 18,6 & 33,3 & 28 \\
\hline $1 / 12 / 1988$ & $2,1 / 4 / 5,5 / 7 / 13$ & 18,6 & 28 & - \\
\hline $1 / 01 / 1989$ & $2,1 / 5,5 / 13$ & 18,6 & 28 & - \\
\hline $8 / 09 / 1989$ & $2,1 / 5,5 / 13$ & 18,6 & $25 / 28$ & - \\
\hline $1 / 01 / 1990$ & $2,1 / 5,5 / 13$ & 18,6 & 25 & - \\
\hline $13 / 09 / 1990$ & $2,1 / 5,5 / 13$ & 18,6 & 22 & - \\
\hline 29/07/1991 & $2,1 / 5,5$ & 18,6 & 22 & - \\
\hline $1 / 01 / 1993$ & $2,1 / 5,5$ & 18,6 & - & - \\
\hline $1 / 08 / 1995$ & $2,1 / 5,5$ & 20,6 & - & - \\
\hline $1 / 04 / 2000$ & $2,1 / 5,5$ & 19,6 & - & - \\
\hline \multicolumn{5}{|c|}{ IRELAND } \\
\hline $1 / 11 / 1972$ & $1 / 5,26$ & 16,37 & 30,26 & 11,11 \\
\hline $3 / 09 / 1973$ & $1 / 6,75$ & 19,5 & 36,75 & 11,11 \\
\hline $1 / 03 / 1976$ & 10 & 20 & $35 / 40$ & - \\
\hline $1 / 03 / 1979$ & $1 / 10$ & 20 & - & - \\
\hline $1 / 05 / 1980$ & $1 / 10$ & 25 & - & - \\
\hline $1 / 09 / 1981$ & $1,5 / 15$ & 25 & - & - \\
\hline $1 / 05 / 1982$ & $1,8 / 18$ & 30 & - & - \\
\hline $1 / 03 / 1983$ & $2,3 / 23$ & 35 & - & - \\
\hline $1 / 05 / 1983$ & $2,3 / 5 / 18$ & $23 / 35$ & - & - \\
\hline $1 / 07 / 1983$ & $2 / 5 / 18$ & $23 / 35$ & - & - \\
\hline $1 / 05 / 1984$ & $2 / 5 / 8 / 18$ & $23 / 35$ & - & - \\
\hline $1 / 03 / 1985$ & $2,2 / 10$ & 23 & - & - \\
\hline $1 / 03 / 1986$ & $2,4 / 10$ & 25 & - & - \\
\hline $1 / 05 / 1987$ & $1,7 / 10$ & 25 & - & - \\
\hline $1 / 03 / 1988$ & $1,4 / 5 / 10$ & 25 & - & - \\
\hline $1 / 03 / 1989$ & $2 / 5 / 10$ & 25 & - & - \\
\hline $1 / 03 / 1990$ & $2,3 / 10$ & 23 & - & - \\
\hline
\end{tabular}




\begin{tabular}{|c|c|c|c|c|}
\hline $1 / 03 / 1991$ & $2,3 / 10 / 12,5$ & 21 & - & - \\
\hline $1 / 03 / 1992$ & $2,7 / 10 / 12,5$ & 21 & - & 16 \\
\hline $1 / 03 / 1993$ & $2,5 / 12,5$ & 21 & - & 12,5 \\
\hline $1 / 01 / 1996$ & $2,8 / 12,5$ & 21 & - & 12,5 \\
\hline $1 / 03 / 1997$ & $3,3 / 12,5$ & 21 & - & 12,5 \\
\hline $1 / 03 / 1998$ & $3,6 / 12,5$ & 21 & - & 12,5 \\
\hline $1 / 03 / 1999$ & $4 / 12,5$ & 21 & - & 12,5 \\
\hline $1 / 03 / 2000$ & $4,2 / 12,5$ & 21 & - & 12,5 \\
\hline $1 / 01 / 2001$ & $4,3 / 12,5$ & 20 & - & 12,5 \\
\hline $1 / 03 / 2002$ & $4,3 / 12,5$ & 21 & - & 12,5 \\
\hline $1 / 01 / 2003$ & $4,3 / 13,5$ & 21 & - & 13,5 \\
\hline $1 / 01 / 2004$ & $4,4 / 13,5$ & 21 & - & 13,5 \\
\hline $1 / 01 / 2005$ & $4,8 / 13,5$ & 21 & - & 13,5 \\
\hline $1 / 12 / 2008$ & $4,8 / 13,5$ & 21,5 & - & 13,5 \\
\hline $1 / 01 / 2010$ & $4,8 / 13,5$ & 21 & - & 13,5 \\
\hline \multicolumn{5}{|c|}{ ITALY } \\
\hline $1 / 01 / 1973$ & 6 & 12 & 18 & - \\
\hline $1 / 01 / 1975$ & 6 & 12 & 30 & 18 \\
\hline 18/03/1976 & 6 & 12 & 30 & 18 \\
\hline $10 / 05 / 1976$ & $6 / 9$ & 12 & 30 & 18 \\
\hline $23 / 12 / 1976$ & $1 / 3 / 6 / 9$ & 12 & 30 & 18 \\
\hline $8 / 02 / 1977$ & $1 / 3 / 6 / 9 / 12$ & 14 & 35 & 18 \\
\hline $3 / 07 / 1980$ & $2 / 8$ & 15 & 35 & 18 \\
\hline $1 / 11 / 1980$ & $1 / 2 / 3 / 6 / 9 / 12$ & 14 & 35 & $15 / 18$ \\
\hline $1 / 01 / 1981$ & $2 / 8$ & 15 & 35 & 18 \\
\hline $5 / 08 / 1982$ & $2 / 8 / 10 / 15$ & 18 & 38 & 20 \\
\hline $19 / 04 / 1984$ & $2 / 8 / 10 / 15$ & 18 & $30 / 38$ & 20 \\
\hline $20 / 12 / 1984$ & $2 / 9$ & 18 & 30 & - \\
\hline $1 / 08 / 1988$ & $2 / 9$ & 19 & 38 & - \\
\hline $1 / 01 / 1989$ & $4 / 9$ & 19 & 38 & - \\
\hline $13 / 05 / 1991$ & $4 / 9 / 12$ & 19 & 38 & - \\
\hline $1 / 01 / 1993$ & $4 / 9$ & 19 & - & 12 \\
\hline $1 / 01 / 1994$ & $4 / 9$ & 19 & - & 13 \\
\hline 24/02/1995 & $4 / 10$ & 19 & - & 16 \\
\hline 1/10/1997 & $4 / 10$ & 20 & - & - \\
\hline \multicolumn{5}{|c|}{ CYPRUS } \\
\hline $1 / 07 / 1992$ & - & 5 & - & - \\
\hline $1 / 10 / 1993$ & - & 8 & - & - \\
\hline $1 / 07 / 2000$ & 5 & 10 & - & - \\
\hline $1 / 07 / 2002$ & 5 & 13 & - & - \\
\hline $1 / 01 / 2003$ & 5 & 15 & - & - \\
\hline $1 / 08 / 2005$ & $5 / 8$ & 15 & - & - \\
\hline \multicolumn{5}{|c|}{ LATVIA } \\
\hline $1 / 05 / 1995$ & - & 18 & - & - \\
\hline $1 / 01 / 2003$ & 9 & 18 & - & - \\
\hline $1 / 05 / 2004$ & 5 & 18 & - & - \\
\hline $1 / 01 / 2009$ & 10 & 21 & - & - \\
\hline \multicolumn{5}{|c|}{ LITHUANIA } \\
\hline $1 / 05 / 1994$ & - & 18 & - & - \\
\hline $1 / 08 / 1994$ & 9 & 18 & - & - \\
\hline $1 / 01 / 1997$ & - & 18 & - & - \\
\hline $1 / 05 / 2000$ & 5 & 18 & - & - \\
\hline $1 / 01 / 2001$ & $5 / 9$ & 18 & - & - \\
\hline
\end{tabular}




\begin{tabular}{|c|c|c|c|c|}
\hline $1 / 01 / 2009$ & $5 / 9$ & 19 & - & - \\
\hline $1 / 09 / 2009$ & $5 / 9$ & 29 & - & - \\
\hline \multicolumn{5}{|c|}{ LUXEMBURG } \\
\hline $1 / 01 / 1970$ & 4 & 8 & - & - \\
\hline $1 / 01 / 1971$ & $2 / 5$ & 10 & - & - \\
\hline $1 / 07 / 1983$ & $3 / 6$ & 12 & - & - \\
\hline $1 / 01 / 1992$ & $3 / 6$ & 15 & - & - \\
\hline $1 / 01 / 1993$ & $3 / 6$ & 15 & - & 12 \\
\hline \multicolumn{5}{|c|}{ HUNGARY } \\
\hline $1 / 01 / 1988$ & $0 / 15$ & 25 & - & - \\
\hline $1 / 01 / 1993$ & $0 / 6$ & 25 & - & - \\
\hline $1 / 08 / 1993$ & 10 & 25 & - & - \\
\hline $1 / 01 / 1995$ & $0 / 12$ & 25 & - & - \\
\hline $1 / 01 / 2004$ & $5 / 15$ & 25 & - & - \\
\hline $1 / 01 / 2006$ & $5 / 15$ & 20 & - & - \\
\hline $1 / 09 / 2006$ & 5 & 20 & - & - \\
\hline $1 / 07 / 2009$ & $5 / 18$ & 25 & - & - \\
\hline \multicolumn{5}{|c|}{ MALTA } \\
\hline $1 / 01 / 1995$ & 5 & 15 & - & - \\
\hline $1 / 01 / 1999$ & 5 & 15 & - & - \\
\hline $1 / 01 / 2004$ & 5 & 18 & - & - \\
\hline \multicolumn{5}{|c|}{ NETHERLANDS } \\
\hline $1 / 01 / 1969$ & 4 & 12 & - & - \\
\hline $1 / 01 / 1971$ & 4 & 14 & - & - \\
\hline $1 / 01 / 1973$ & 4 & 16 & - & - \\
\hline $1 / 01 / 1976$ & 4 & 18 & - & - \\
\hline $1 / 01 / 1984$ & 5 & 19 & - & - \\
\hline $1 / 10 / 1986$ & 6 & 20 & - & - \\
\hline $1 / 01 / 1989$ & 6 & 18,5 & - & - \\
\hline 1/10/1992 & 6 & 17,5 & - & - \\
\hline $1 / 01 / 2001$ & 6 & 19 & - & - \\
\hline \multicolumn{5}{|c|}{ AUSTRIA } \\
\hline $1 / 01 / 1973$ & 8 & 16 & - & - \\
\hline $1 / 01 / 1976$ & 8 & 18 & - & - \\
\hline $1 / 01 / 1978$ & 8 & 18 & 30 & 30 \\
\hline $1 / 01 / 1981$ & $13 / 8$ & 18 & 30 & 30 \\
\hline $1 / 01 / 1984$ & 10 & 20 & 32 & 32 \\
\hline $1 / 01 / 1992$ & 10 & 20 & - & - \\
\hline $1 / 01 / 1995$ & 10 & 20 & - & 12 \\
\hline \multicolumn{5}{|c|}{ POLAND } \\
\hline $8 / 01 / 1993$ & $3 / 7$ & 22 & - & - \\
\hline \multicolumn{5}{|c|}{ PORTUGAL } \\
\hline $1 / 01 / 1986$ & 8 & 16 & 30 & - \\
\hline $1 / 02 / 1988$ & 8 & 17 & 30 & - \\
\hline $24 / 03 / 1992$ & 5 & 16 & 30 & - \\
\hline $1 / 01 / 1995$ & 5 & 17 & - & - \\
\hline $1 / 07 / 1996$ & $5 / 12$ & 17 & - & - \\
\hline $5 / 06 / 2002$ & $5 / 12$ & 19 & - & 12 \\
\hline $1 / 07 / 2005$ & $5 / 12$ & 21 & - & 12 \\
\hline $1 / 07 / 2008$ & $5 / 12$ & 20 & - & 12 \\
\hline $1 / 07 / 2010$ & $6 / 13$ & 21 & - & 13 \\
\hline \multicolumn{5}{|c|}{ ROMANIA } \\
\hline $01 / 07 / 1993$ & - & 18 & - & - \\
\hline
\end{tabular}




\begin{tabular}{|c|c|c|c|c|}
\hline 01/01/1995 & 9 & 18 & - & - \\
\hline 01/02/1998 & 11 & 22 & - & - \\
\hline $01 / 01 / 2000$ & - & 19 & - & - \\
\hline $01 / 01 / 2004$ & 9 & 19 & - & - \\
\hline $01 / 12 / 2008$ & $5 / 9$ & 19 & - & - \\
\hline 01/07/2010 & $5 / 9$ & 24 & - & - \\
\hline \multicolumn{5}{|c|}{ SLOVENIA } \\
\hline $1 / 07 / 1999$ & 8 & 19 & - & - \\
\hline $1 / 01 / 2002$ & 8,5 & 20 & - & - \\
\hline \multicolumn{5}{|c|}{ SLOVAK REPUBLIC } \\
\hline $1 / 01 / 1993$ & 5 & 23 & - & - \\
\hline $1 / 08 / 1993$ & 6 & 25 & - & - \\
\hline $1 / 01 / 1996$ & 6 & 23 & - & - \\
\hline 1/07/1999 & 10 & 23 & - & - \\
\hline $1 / 01 / 2003$ & 14 & 20 & - & - \\
\hline $1 / 01 / 2004$ & - & 19 & - & - \\
\hline $1 / 01 / 2007$ & 10 & 19 & - & - \\
\hline $1 / 05 / 2010$ & $6 / 10$ & 19 & - & - \\
\hline \multicolumn{5}{|c|}{ FINLAND } \\
\hline $1 / 06 / 1994$ & $12 / 5$ & 22 & - & - \\
\hline $1 / 01 / 1995$ & $17 / 12 / 6$ & 22 & - & - \\
\hline $1 / 01 / 1998$ & $17 / 8$ & 22 & - & - \\
\hline $1 / 10 / 2009$ & $12 / 8$ & 22 & - & - \\
\hline $1 / 07 / 2010$ & $13 / 9$ & 23 & - & - \\
\hline \multicolumn{5}{|c|}{ SWEDEN } \\
\hline $1 / 01 / 1969$ & $6,38 / 2,04$ & 11,11 & - & - \\
\hline 1/01/1971 & $9,89 / 3,09$ & 17,65 & - & - \\
\hline $1 / 06 / 1977$ & $11,43 / 3,54$ & 20,63 & - & - \\
\hline 8/09/1980 & $12,87 / 3,95$ & 23,46 & - & - \\
\hline 16/11/1981 & $11,88 / 3,67$ & 21,51 & - & - \\
\hline $1 / 01 / 1983$ & $12,87 / 3,95$ & 23,46 & - & - \\
\hline $1 / 07 / 1990$ & $13,64 / 4,17$ & 25 & - & - \\
\hline $1 / 01 / 1992$ & 18 & 25 & - & - \\
\hline $1 / 01 / 1993$ & 21 & 25 & - & - \\
\hline $1 / 07 / 1993$ & $21 / 12$ & 25 & - & - \\
\hline $1 / 01 / 1996$ & $6 / 12$ & 25 & - & - \\
\hline \multicolumn{5}{|c|}{ UNITED KINGDOM } \\
\hline $1 / 04 / 1973$ & - & 10 & - & - \\
\hline 29/07/1974 & - & 8 & - & - \\
\hline 18/11/1974 & - & 8 & 25 & - \\
\hline $12 / 4 / 1976$ & - & 8 & 12,5 & - \\
\hline $18 / 06 / 1979$ & - & 15 & - & - \\
\hline 1/04/1991 & - & 17,5 & - & - \\
\hline $1 / 04 / 1994$ & 8 & 17,5 & - & 8 \\
\hline $1 / 01 / 1995$ & 5 & 17,5 & - & - \\
\hline $1 / 09 / 1997$ & 5 & 17,5 & - & - \\
\hline $1 / 12 / 2008$ & 5 & 15 & - & - \\
\hline $1 / 01 / 2010$ & 17,5 & - & - & \\
\hline
\end{tabular}

Source: European Commission, VAT Rates Applied in the Memeber States of the European Union, 1049 Brussels, [Online]: http://ec.europa.eu/taxation_customs/resources/documents/taxation/vat/how vat_works/rates/vat_rates_en.pdf, pp.23-27. 